\title{
Ethnic Federalism and the Developmental State: The Search for Balance in Ethiopia
}

\author{
Girma Mekonnen \\ Lecturer, Department of Civics and Ethical Studies, Debre Markos University, Ethiopia
}

\begin{abstract}
Contrary to most Africa states, Ethiopia since 1990s reconfigures the country along ethnic lines. Despite many hopes and expectation, the restructuring of the country under ethnic federalism doomed to consolidate ethnic peace. Besides, the political economy of 'developmental state' has become the state ideology following the disgraceful 2005 national election in the country. However, sporadic ethnic-based conflict and animosities become the rule of the game and pose a serious challenge to the state-building project of replicating East Asian version of developmental state ideology. The politics of identity and representation, ethnicity and language issues, secession claims, and unsettled regional boundary issues polarised the country and the aspiration of the state to build a democratic developmental state in the Horn of Africa. The state failure to balance ethnic federalism and developmental state makes the country still one of the poorest countries in the world with a per capita income of $\$ 706$ and subsistence agricultural economy.
\end{abstract}

DOI: $10.7176 / \mathrm{IAGS} / 76-03$

Publication date:September $30^{\text {th }} 2019$

\section{Introduction}

The developmental state experience of South East Asian states reveals the relevance of the state ideological hegemony and institutional structure which are the two most important pillars of the 'developmental state' (Mkandawire, 2001). The "ideology-structure nexus [...] distinguishes developmental states from other forms of states ." (Mkandawire, 2001 p. 290). It has been often argued that the replication of the East Asian model of state-led development in Africa becomes proliferated for the past two decades and it generates mixed reactions from various development experts. Besides, the discussion of the 'developmental state' has become an area of top developmental issues in postindependence Africa.

The East Asian state-led development practice indicates that nationalism is an important factor to explain the success of the developmental state. The state ideology is expressed in the form of nationalism, state aspiration and shared vision towards economic development and state-building. To be successful, "élite must be able to establish an 'ideological hegemony", so that its developmental project becomes, in a Gramscian sense, a "hegemonic" project to which key actors in the nation adhere voluntarily" (Mkandawire, 2001 p. 290). Besides, it is the interaction of state ideology and state structure resulted in successful development state or conversely failed state (Mkandawire, 2001; Fritz \& Rocha Menocal, 2007; Leftwich, 1995). Perhaps, state capacity also matters to convert development objectives to positive outcomes.

In the same vein, the structural features of the 'developmental state' require state capacity to effectively handle national economic policies (Mkandawire, 2001). Mkandawire (2001) has further argued that "the essential features that characterized successful developmental states are a strong core of state institutions with the capacity to promote economic growth without being "captured by particular interests groups" (p. 290).

To do So, strong state autonomy and state-society relation considered as an engine for strong states. Leftwich (1995, p. 408) define state autotomy as the "state ability to achieve relative insulation from the clamour of special interests". Establishing Weberian rationalized bureaucracy coupled with 'embedded autonomy' is therefore considered a powerful weapon to control clientelism and corruption in the developmental state (Leftwich, 1995; Evan, 1995). Taking to account the various salient attributes of the developmental state, this paper examines how ethnic federalism in Ethiopia and the state 'developmental state' narratives reconciled to realize the state aspiration of becoming a 'democratic developmental state' in the Horn of Africa

\section{Significance and Justification of the study}

Despite its varying applicability, ethnic federalism can be understood as institutional mechanisms of powers sharing among constitutionally established sub territorial units within the state jurisdiction. Of course, the accommodation of minority nationalism through some forms of territorial autonomy has increasingly become a common trend for the past few decades. In Africa However, a majority of Africa states consider ethnicity as a potential threat for national unity and nation-building process. As a result of this, most states are less interested to restructure their country along ethnic lines (Aalen, 2011; Turton, 2006).

Contrary to most Africa states, Ethiopia however, reconfigures the country along ethnic lines in 1991 (Turton, 2006). Besides, the political economy of 'development state' becomes the state ideology following the disgraceful 2005 national election in the country (Clapham, 2017; De Waal, 2012). Despite many hopes and 
expectation, the restructuring of the country under ethnic federalism doomed to consolidate ethnic peace. Sporadic ethnic-based conflict and animosities become the rule of the game and pose a serious challenge to the state-building project of replicating East Asian version of developmental state ideology. The politics of identity and representation, ethnicity and language issues, secession claims, and unsettled regional boundary issues polarised the country and the aspiration of the state to build a democratic developmental state in the Horn of Africa.

Failure to balance ethnic federalism and developmental state makes the country still one of the poorest countries in the world with a per capita income of $\$ 706$ and subsistence agricultural economy (World Bank, 2016; Bahru, 1991). This paper, therefore, argues that the politics of ethnic federalism erodes the national feelings of citizens which in turn affects the state capacity to implement developmental policies. Particularly, non-meritocracy or ethnic-based recruitments and selection process undermine the technical competences of bureaucrats. Put differently, ethnic federalism creates fertile conditions for politicians and bureaucrats to build a basis of political support by manipulating the imperfect market. The main objective of this paper is, therefore, to examine how ethnic federalism challenges the state aspiration of becoming a democratic developmental state. Particularly, it analyzes how ethnic federalism obscure the state ability to build two strong components of the 'developmental state': Nationalism (ideology) and powerful, insulated and competent bureaucracy (state structure (Mkandawire, 2001; Leftwich, 1995).

\section{Material and Methods}

Methodologically, the study uses a qualitative desk research approach to develop the theoretical framework and to present and analyze the major findings of the study. Accordingly, the study uses the existing theories and debates on the 'developmental state' discourses ethnicity, and federalism and other empirical research studies so as to examine the paradoxical state policy of Ethiopia. The literature survey for the theoretical chapter and the discussion is mainly based on secondary sources, blogs, public opinions, press realises, previous studies and academic journals and historical books. It is commonly known that qualitative research design is a panacea to explore and understand the multiple realities of societal problems in a complex setting (Creswell, 2008).

\section{Theoretical Perspectives and Literature Review}

\subsection{The 'developmental state' origin}

The early twentieth-century history of the modern states shows that state-led development particularly focuses on building a strong army, building democracy, provide welfare and enhance economic growth (Leftwich, 2012). In the mid-1950s, the post-war economic success of Europeans under 'Marshal plans' motivated development scholars to replicate the trends in the newly independent developing countries. Authoritarian states in developing were, therefore, seen as a panacea to build strong state economy and huge capital formation. However, that did not happen and the period 1960s and 70s leads to the emergence of the market-led development with minimum state intervention. However, the 19980s structural adjustments programs pervasive effects complicate the quest for development in developing countries (Mkandawire, 2001; Wade, 1990).

Conversely, some countries registered impressive economic growth from the period 1965 to 1990s. This remarkable achievement for Leftwich (1995, p. 401) is "the presence of a particular type of state, a "developmental state" which must be understood politically". Therefore, it possibly supposes that the failure of the structural adjustment program and the economic success of East Asia' states reinforced the replication of the 'developmental state' ideology ${ }^{1}$ to the global south (Leftwich, 1995; Singh, 2017).

\subsection{The 'developmental State' Concept}

Commenting on the 'developmental state' Leftwich (1995, p. 401) stated that "fundamentally political factors have always shaped the thrust and pace of their development strategies through the structures of the state". The quest for prosperity, internal and external vulnerability, nationalism, need for unity, legitimacy, are political factors (Leftwich, 1995). Unlike centrally planned economy or market-led development, the unique attributes of a developmental state are their ability to manage the complex market forces through the intuition of mechanism where the role of state presence is unquestionably strong. In that case, the ultimate source of developmental state success found in their ability to create coherent state apparatus pair with private investors to accelerate economic growth and improve their societal wellbeing (Evans, 1995). Most importantly, establishing a strong tie between state and society plus a meritocratic bureaucracy is considers as a solution to handle the complexities of the market. In his work on 'Embedded Autonomy', Evans's (1995, p. 50) value the essentiality of such kind of embeddedness to "increased competence".

It is now clear that politics is the central factor for the origin of a particular type of state called developmental state. Leftwich's developmental state and Evans analysis of Embedded autonomy tell us the 
inseparable features of state autonomy and state-society relation. Both are complementary and have the capacity to create varying degrees of developmental outcomes (Evans, 1995; Leftwich, 1995). In other words, embeddedness and autonomy are inherent features of the developmental state. While a variety of definitions of the term 'developmental state' have been suggested, this paper uses the definition suggested by Leftwich (1995, p. 401) who defined it as:

"states whose politics have concentrated sufficient power, autonomy, and capacity at the centre to shape, pursue and encourage the achievement of explicit developmental objectives, whether by establishing and promoting the conditions and direction of economic growth, or by organizing it directly, or a varying combination of both".

This definition has two strengths. First, it is representative and encompasses developmental state experience of Southeast Asia and Africa. Second, the definition shows the basic attributes of the 'development state'. These components are stated in Leftwich model of the developmental state (1995, p. 405) as:

" a determined developmental elite; relative autonomy; a powerful, competent and insulated economic bureaucracy; a weak and subordinated civil society; the effective management of non-state economic interests; and repression, legitimacy, and performance”.

\subsection{The Salient components of the 'developmental state'}

The state ideology and capacity basically emanated from internal and external factors like national security, coemption, threats, poverty, legitimacy, history, war, and location that put states in a 'systemic vulnerability'. So, states to exist, these sources of ideologies motivate leaders or elite to undergo transformation by mobilizing the society (Fritz \& Menocal, 2007; Singh, 2017). The two most important attributes of development states are their ability of posseting strong ideological hegemony coupled with the capacity of generating positive development outcomes. The success and failure of developing countries found on these two complementary attributes. The mere possession of ideological hegemony is not an end by itself. The state structure also matters to effectively implement development policies.

\subsubsection{Ideology}

Mkandawire (2001) stated that a strong sense of nationhood with the effective government is a panacea for nation-building project and development in Africa. The ability to articulate a strong vision and state policy, establishing ideological hegemony, expanding sources of legitimacy, demonstrating strong leadership and capacity of policy implementation are some of the salient attributes of developmental states (Evans, 1995; Johnson 1992; Mkandawire. 2001).

In relation to ideology, the state should articulate developmental ideology to generate high capital formation, high economic growth, and industrialization. The state vision and ideology basically emanated from internal and external factors like national security, coemption, threats, poverty, legitimacy, history, war, and location that put states in a 'systemic vulnerability'. So, states to exist, these sources of ideologies motivate leaders or elite to undergo transformation by mobilizing the society (Fritz \& Menocal, 2007; Singh, 2017). Mkandawire's (2001, p. 290) statement on ideological hegemony of state deserves long to cite here.

"[i]n terms of ideology, a developmental state is essentially one whose ideological underpinning is 'developmental' [...] its 'mission' as that of ensuring economic development, usually interpreted to mean high rates of accumulation and industrialization. Such a state 'establishes as its principle of legitimacy its ability to promote sustained development [...] At the ideational level, the élite must be able to establish an 'ideological hegemony ', so that its developmental project becomes, in a Gramscian sense, a 'hegemonic' project to which key actors in the nation adhere voluntarily".

However, establishing ideological hegemony requires a unified sense of belongingness and nationhood. It can be expressed through, ethnic peace, nationhood, shared aspiration, common cause, collective interest, pride, unity with diversity. In other words, the personal qualities of leaders play a significant role to develop a strong sense of nationhood. For example, altruistic qualities of leaders, their nationalistic aspiration, their commitment and ability of managing complex web of social interaction matters determine for the success or failure of the nations.

\subsubsection{State Structure}

The second unique component of development state is stated structure, the state ability to convert development objectives into positive outcomes. To successfully implement development strategies, the state should systematically analyze "various factors intuitional, technical, administrative, and political" (Mkandawire, 2001, p. 290). Establishing state autonomy is the determinant factors to successfully implement development objectives. Sate autonomy demands professionalized, competent and meritocracy bureaucracy. To become a strong state, the state should overcome or manage private non-economic forces. To do so, the state should establish what Evans (1995) call 'embedded autonomy'. On the one hand, promoting professionalism and meritocratic selection of bureaucrats. On the other hand, elite commitment to establish a close relationship with 
society (Mkandawire, 2001; Evans, 1995; Leftwich, 1995)

In nutshell, ideology- structure nexus differentiate developmental state form other states. However, it is important to bear in mind the possible politicization of ideology and structure. Unless appropriate proxies like the quest of "technocratic "governance" (Mkandawire, 2001, p. 290), tax performance and public spending measures are applying, "the definition of developmental state runs the risk being tautological" (Mkandawire, 2001, p. 290). For instance, state ideology should not be only evaluated in terms of outcomes. This because policy by nature takes a long time horizon to generate desirable outcomes ${ }^{1}$. Therefore, taking it into consideration of the elite commitment and determination of development can be one possible proxy to evaluate ideology. Poor economic performance does not mean that countries are a non-developmental state. It may be because of other invisible/unforeseen factors (Mkandawire, 2001).

\subsection{Perspectives to understand ethnicity}

Immediately after the end of the cold war, ethnicity and identity-based violence become a challenge for developing nations. In Ethiopia, Ethnic federalism now becomes modus operandi a for the state-building process coupled with the 'democratic developmental state'. However, the politicization of ethnicity and sporadic ethnicbased violence becomes visible since the 1990s. Therefore, this section first examines the broader argument of ethnicity and later the state response to manage the problem, particularly under federalism.

\subsubsection{Ethnic conflict vs Ethnic Violence}

There is a central difference between ethnic conflict and ethnic violence. It commonly argues that Ethnic conflict is inevitable in a diversified society and common in various forms of government. Perhaps, democratic countries are more exposed to ethnic conflict than authoritarian system if their societal composition is diversified. In the former case, politicians, member of the parliament and other groups express their concern by articulating the voice of a particular ethnic group. This implies that if the political landscapes of the country allow freedom expression, the likelihood of ethnic conflict is high. Debates over resources, identity, languages are inherently institutionalized and seen as an ethnic conflict, not ethnic violence (Varshney, 2002).

Conversely, ethnic violence is mostly contained and when breakout it is destructive. Unlike ethnic conflict, it is sporadic and caused by deep-rooted problems like discrimination, political silence, long period of dissatisfaction. The immediate cause for ethnic violence is mostly linked with government loss of legitimacy. Ethnic violence expresses in the form of riots, civil war and violent demonstration (Varshney, 2002). Hence ethnic peace is not about the absence of ethnic conflict. It is rather the absence of ethnic violence and designing of an institutional mechanism to constructively addressed ethnic-based conflict (Varshney, 2002). In nutshell, Varshney (2002) provides four theoretical explanations about the cause of ethnic violence.

\subsubsection{Essentialism and Instrumentalism}

The central assumption of essentialism is ethnicity is something ascribed at birth and ethnic conflict is inherently liked with the historical differences of ethnic groups. For essentialist, natural incompatibles and animosities among groups are the fundamental causes of ethnic conflict ${ }^{2}$ (Varshney, 2002). In another word, ethnicity is ascribed at birth and defines an ethnic group as a category of a human population that shares attributes such as common origin, history, and culture, language and territory (Barth, 1969 \& Varshney, 2002). However, the historical reality of peaceful coexistence among various ethnic groups in the same geographical setting areas contradicts with the essentialist approach of ethnic conflict (Varshney, 2002).

On the other hand, instrumentalism views ethnicity as manipulated, artificial and a means to achieve political goals or other benefits. To get support, leaders craft stories, myth, traditions, values of a particular group. Leaders exactly know that individual as are willing to attach themselves to their natural groups even without any expressed interstate. This indicates that natural group difference and animosities are nothing for leaders but "focal point for mobilization" (Varshney, 2002). However, mobilizing groups for the sake of political positions depends on individual willingness. Mostly, individuals are either unwilling or fear the social cost of ethnic conflict also matters. In nutshell, "[essentialist] focuses on the intrinsic power of ethnic differences, [instrumentalist] concentrates on their instrumental value, political or economic" (Varshney, 2002 p. 27).

\subsubsection{Constructivism and Institutionalism}

The underlying assumption of this theory is the existence of a strong relationship between ethnic conflict and political institutions. The political institutions of a country, for instance, electoral systems, forms of government, state structure determine the prevalence of ethnic peace or conflict. Lijphart's 'consociationalism' is, for example, one intuitional mechanism used to handling ethnic conflict in a pluralistic society. Lijphart in Varshney (2002, p. 37) explains that

"[a]plural society is defined as one in which the various ethnic groups are segmented and have little criss-

\footnotetext{
${ }^{1}$ Mkandawire (2001), Latin America development state have strong ideology, however, unforeseen factors obscures its success.

${ }^{2}$ Varshney (2002, p. 28) "Conflict between Hindus and Muslims, Serbs and Croats, Arabs and Jews, whites and blacks, Catholics and Protestants, Hutu and Tutsi take the phrases 'old animosities,' 'tribalism,' and 'ties of blood".
} 
crossing. Elite compromise can best be assured by a political system that works on intergroup consensus, not intergroup competition. A consensual democracy of this kind can be called consociational"

Federalism is also another institutional mechanism used to manage ethnic diversity. It is a constitutional mechanism of allocating power between the central and regional levels of federating units. (International IDEA, 2017). The devolution of power can be either between the central or regional state or more level of overlapping territorial and linguistic federation. Federalism thereby allows distinct communities, defined by their territorial boundaries, to exercise guaranteed autonomy over certain matters of importance to them while being part of a larger federal union through which shared powers and responsibilities are exercised over matters of common concern. In other words, states use either identity or efficiency parameters to organize the state (International IDEA, 2017).

Federalism has both opportunities and challenges. It could be a means of ensuring the equality of various ethnic groups and enhance mutual accommodation. Federalism, especially in large or diverse countries, can also improve public delivery and promote democratic participation, give confidence for federating, protect centralization of power and in general create more opportunities for unity with diversity. However, can also worsen prevailing differences, sometimes leading to protracted conflicts or state failure. Federalism is also a complicated, often legalistic, form of government, which can be expensive and can hinder the coherent development and application of policies (International IDEA, 2017).

In nutshell, the state adopts federalism to accommodate diversities of ethnic, religious, cultural and/or linguistic. It is used for greater public participation in the decision making the process and an effort to make service distribution more responsive to the people concerned (International Idea, 2017). However, the actual state practice, the elite political ideology, and the contradictory state-building process also matter to effectively implement the legal and institutional principles of federalism. In Ethiopia, for instance, the current ruling party, the coalition of Ethiopian People Revolutionary Democratic Front (hereafter EPRDF) overthrown the military regime and marked the birth of Ethnic federalism in Ethiopia in 1991. Since then, the restructuring of the state under ethnic federalism marked the proliferation of various ethnic groups. The constitution further recognizes the right of 'self-determination including succession' to various ethnic groups (Vaughan, 2012; Clapham, 2017; Abay, 2009). However, coupled with the problem of good governance, it leads to the emergence of ethnic-based conflict.

\section{Results and discussion}

\subsection{Economic Growth vs. political development}

Before the 1974 Ethiopia revolution, the country borrowed development policies from Russia, Japan, the United Kingdom, and other western worlds. In the turn o of the 20th century, Soviet's centrally planned economy dominated the economy of the country. Perhaps, senior member of the current ruling party including late prime minister Meles Zenawi was ardent supporter of Stalin ideology nationalism (Clapham, 2006). In his work on the politics of "emulation' in Ethiopia (Clapham, 2006, p. 108) argues that "[n]one of these models has "worked" [...] the search for an "Ethiopian road to development" remains unfulfilled". After ten years, the same person states that "Ethiopia provides one of the clearest examples of a "developmental state" in Africa" (Clapham, 2017, p.1).

As far as concerned the current EPRDF ideological narrative, the creation of Marxist-Leninist League of Tigray (MLLT) on 25 July 1985 considered as the first matured guiding ideology of the then Tigray People Liberation Front (TPLF). Refined by Meles Zenawi, the late prime minister of Ethiopia, MLLT ideology later progressed towards as 'revolutionary democracy'. After the downfall of the military government in 1991, the EPRDF government officially accept the liberalist ideology which later causes friction among senior members of the ruling party. For many scholars and domestic politicians, the policy change was considered as a tactical move designed to get western support (Lefort, 2015). The rationale behind for such could be the EPRDF leadership style secretly seems Marxism and Leninist under 'democratic centralism' which fitted with the long culture of Abyssinia old age of hierarchy form of government (Clapham, 2017; Lefort, 2015).

Over the last decades, Ethiopia registered the second-fastest economic growth next Angola under the leadership of EPRDF (Clapham, 2017). The country also shows key progress in human many of the development indicators Education and health improvement, poverty reduction, primary school enrollment, reduction of child mortality. According to WB (2010), poverty headcount ratio at national poverty lines declines from $45 \%$ in 1995 to $29.6 \%$ in 2010. The infrastructural development (railways, electric, road highway, big dams (WB, 2010).

Under the leadership of the late prime minister, Meles Zenawi, the state proclaimed 'fundamental' political and economic policies: Particularly, ethnic federalism (including self-determination 'revolutionary democracy', and the 'democratic developmental state' becomes the state guiding ideology. The current ruling party appears to 'download' the developmental state software of East Asia 'Tigers' (Asnake, 2013; Lefort, 2015). The current ruling party appears to 'download' the developmental state software of East Asia's tigers (Lefort, 2015).

Another controversial aspect in the 'developmental state' claim in Ethiopia is why should the EPRDF 
government decided to add the phrase 'democratic' without even have the necessary political will to open the space for democratic completions. It is possible to argue that democracy is a secondary thing in Ethiopia. In his speech, the late prime minister clearly indicated the impracticality of the liberal democracy in Ethiopia.

Arguing against democracy, Meles in De Waal (2012, p. 154) "condemned liberal formulae as 'trickle-up democracy' and said that, in a poor developing nation, political parties and NGOs would easily become patronage mechanisms." Perhaps, the hybridization of democracy with development at rhetorical helps the ruling government to get a high amount of foreign aid forms the western world. Conversely, a formal election on the basis of five years so far becomes a source of social conflict and unrest. The quest for democracy is one of the major sources of the ongoing conflict in Ethiopia and the country shows even a "dramatic decline in freedom" (Freedom House, 2018)

\subsection{Ethnic Conflict vs state Capacity}

On the one hand, the government is advertising the economic and infrastructural progress of the country. On the other side, the country is plagued by identity and ethnic-based conflict since 2016. Discontent and frustration billowed across the country. This mixed success is against the very broad objective building a democratic developmental state (BTI, 2016). Mkandawire (2001) analysis of the 'developmental state' shows that economic outcome is not an end by itself for developmental state. Though the broader literature on Ethiopia shows fast economic growth, the impact of this economic growth has, however, had led to only small improvements in the plight of the poor. There are still undeniable obstacles within the federal system: prevailing patron-client relationships, constraints on state capacity to efficiently and effectively implement policy, and bureaucratic rentseeking in the provision of public goods (Lefort, 2015).

Stating on the complexities of the Ethiopian ethnic-based conflict and federalism, Alem (2004) argues that the success and failures found on in the hands of the EPRDF led government. It is difficult to predict what will happen in the future. Surly, unitary form of government will not back in. He further added that "the viability [...] of ethnic federalism is indeterminate. Contingent events will shape the outcome of the politically fragile ethnic federal experiment. For now, the stability of the infant political system is dependent on the dominant front (EPRDF)" (Alem, 2004, p. 115).

\subsection{Ethiopia Ethnic Federalism vs State Capacity}

Mkandawire (2001) conceptualizing of the 'developmental state reveals that the ideological hegemony of developmental state requires articulated development roles and a unified sense of nationhood. It has been expressed through the existence of ethnic peace, nationhood, shared aspiration, common cause, collective interest, pride, unity with diversity. However, ethnicity related tensions continue to challenge the state aspiration. Concerning the politics of ethnicity in Ethiopia, politicians and scholars provide three fundamental explanation for this problem.

First, the EPRDF regime firmly argues that ethnic federalism addresses the long questions of nationalities and prevent the escalation of further conflict. Scholars also support the policy measure hoping that the restructuring of the country under multi-ethnic federation stops further disintegration and ethnic-based conflict (Mengisteab; Vaughan; Young in Asnake, 2013). The EPRDF proposal of ethnic federalism is linked with the institutionalism theory of ethnicity which requires strong political structure best accommodate diversity and pluralism.

Still, others consider it as the EPRDF tactical move to consolidate its power under ethnic division (Aalen in Asnake, 2013). Politicians, academicians, and the diaspora community also strongly criticized the selfdetermination rights of each ethnic groups. They claim that ethnic federalism reduces the collective identity of individuals, exacerbate nationalism and lead to succession. According to Clapham in Asnake (2013, p. 882) "[e]thnic federalism has been also unsuccessful in accommodating many [...] Ethiopians who wish to identify themselves first as Ethiopians [...], the EPRDF shares a paradoxical similarity with its predecessors, that is, obstinate refusal to accommodate different conceptions of Ethiopian statehood".

Besides such contradictory interpretation on ethnic federalism, the actual practice also generates complex problems. The regional unit autonomous power is strongly obscured by the central government under the principle of democratic centralism. Moreover, the constitutional framework of the equality of nation and nationalities upon self-government rarely applies. This hierarchal arrangement of ethnic structure undermines the legitimacy of federation (Asnake, 2013).

Though resource-based conflict and debts are common among multination countries, the economic disparities among nine regional states in Ethiopia complicate the problem. In relation to taxation, the constitution provides concurrent power to both the regional and central government. However, the central government tax base is incomparable. In doing so, the central government annually allocate budget subsidy to each regional state. However, budget formula criticized for being manipulated and incoherent (Asnake, 2013).

Lastly, Ethnic federalism has also aggravated the problem of professionalism in Ethiopia. The government 
has been announcing big state projects including the grand Ethiopian dam which require high technical knowledge and skills. Furthermore, the state must expand revenue under a huge tax base. According (Asnake, 2013), ethnic-based selection of public servants coupled with party membership oversimplify the professional competence of graduates. "there have been widespread complaints that the combined requirements to recruit personnel based on ethnic quotas, and political.

\subsection{Ethnic Federalism in Ethiopia and Conflict}

The current ruling party, the coalition of Ethiopian People Revolutionary Democratic Front (hereafter EPRDF) overthrown the military regime and marked the birth of Ethnic federalism in Ethiopia in 1991. Since then, the restricting of the state under ethnic federalism marked the proliferation of various ethnic groups. The constitution further recognizes the right of 'self-determination including succession' to various ethnic groups (Vaughan, 2012; Clapham, 2017; Abay, 2009). However, the 'legibility' problem of ethnicity immediately preoccupied the nation-building project of the country. Therefore, this section discusses the conceptual framework of federalism (based on Elazar, 1994 and International IDEA, 2017) which help in setting up a framework for observation and examination of the actual working of ethnic federalism in Ethiopia.

According to Elazar (1994), the idea of federalism has a biblical origin. It has first emerged as a 'social contract' of a human being with his own creatures, and then expand to families, groups and finally state level arrangement. It is a constitutional mechanism of dividing power between different levels of government so that federated units can enjoy substantial, constitutionally guaranteed autonomy over certain policy areas while sharing power in accordance with agreed rules over other areas. Thus, federalism combines partial selfgovernment with the partial shared government (Elazar, Cited in IDEA, 2017).

Federalism has both opportunities and challenges. It could be a means of ensuring peace, stability and mutual accommodation in countries that have territorially concentrated differences of identity, ethnicity, religion or language. Federalism, especially in large or diverse countries, can also improve service delivery and democratic resilience, ensure decisions are made at the most appropriate level, protect against the overconcentration of power and resources, and create more opportunities for democratic participation. However, while federalism has helped some countries settle conflicts or improve governance, it can also exacerbate existing differences, sometimes leading to deeper conflicts or state failure. Federalism is also a complicated, often legalistic, form of government, which can be expensive and can hinder the coherent development and application of policies (International IDEA, 2017).

The devolution of power can be either between the central or regional state or more level of overlapping territorial and linguistic federation. Federalism thereby allows distinct communities, defined by their territorial boundaries, to exercise guaranteed autonomy over certain matters of importance to them while being part of a larger federal union through which shared powers and responsibilities are exercised over matters of common concern. In other words, states use either identity or efficiency parameters to organize the state (International IDEA, 2017).

Identity federalism occurs when two or more culturally, linguistically, religiously or otherwise distinct national communities have enough commonality of interest or identity to make them want to live together in one polity, but enough distinctiveness of interest or identity to make them demand substantial autonomy within that polity (e.g. Canada, Switzerland). Efficiency federalism occurs when a culturally homogeneous but geographically large nation wishes to improve democratic representation and accountability by decentralizing power and giving greater control over resources and policies to autonomous units (International IDEA, 2017).

\section{Conclusion}

This paper has discussed the challenges of ethnic federalism in building the democratic developmental state in Ethiopia. It further analyses how ethnic federalism has obscure the coherence implementation of development plans. From the broader literature, Ethiopia is considered is a developmental state or otherwise aspirant developmental state. The successive economics gains in infrastructure, telecommunication, MDGs, and above all double-digit economic growth has been taken as a major parameter concerning Ethiopia. the ideological articulation of by the top elite can be taken as supportive evidence.

However, outcome is not an end by itself. It is also important to bear in mind that "the definition of developmental state runs the risk being tautological" (Mkandawire, 2001, p. 290). The progress in the economy does not mean that state has a 'developmentalism 'vision and capacity. Similarly, development states who have strong development ideology "has fallen into oblivion as a result of the lost decades of the 1980s" (Mkandawire, 2001, p. 291). Studies on Ethiopia also show that the country is still lacking a strong state capacity to negotiate and manage non-economic social forces. Particularly, the dynamics of inter-ethnic conflict require long-lasting institutional response for the EPRDF government.

The elite ability to establish ideological hegemony coupled with competent professional is also a crucial precondition for scholars to make sure the continuity of state-led development. Therefore, the stability of the 
country and the EPRDF political commitment determine the fate of state-led development in Ethiopia. For now, the politicization of ethnicity together with the economic inequality among regional unit seems to deteriorate the strong nationhood of the country. In nutshell, the state proposes federalism to accommodate deep ethnic, religious, cultural and/or linguistic cleavages or to a response to demands for greater public involvement in decision making and an attempt to make service delivery more responsive to the people concerned (International Idea, 2017). However, the actual state practice, the elite political ideology, and the contradictory state-building also matter to effectively implement the legal and institutional $\mathrm{n}$ principles of federalism.

\section{References}

Aalen, L. (2011). The politics of ethnicity in Ethiopia: actors, power, and mobilization under ethnic federalism. Leiden: Brill

Alex de Waal. (2013). The theory and practice of Meles Zenawi. African Affairs,112(446), 148-155. doi: 10.1093/afraf/ads081

Barth, F. (1969). Ethnic Groups and Boundaries: The Social Organization of Culture Difference. Illinois: Waveland Press, Inc. Retrieved from https://books.google.be/books?hl=en\&lr=\&id=QaAQAAAAQBAJ\&oi=fnd\&pg=PA1\&dq=Bart

Evans, P.B., (1995). Embedded Autonomy: states and industrial transformation. Princeton: Princeton University Press.

Fritz, V. \& Menocal, A.R. (2007). Developmental states in the new millennium: concepts and challenges for a New Aid Agenda. Development Policy Review25(5),531-552. doi:10.1111/j.1467-7679.2007. 00384.x

Johnson, C. (1982). MITI and the Japanese miracle: the growth of industrial policy, 1925-1975. Stanford: Stanford university press

Leftwich, A. (2007). Bringing politics back in: towards a model of the developmental state. The Journal of Development Studies, 31(3), 400-427. doi: 10.1080/00220389508422370

Mann, M. (1986). The sources of social power: A history of power from the beginning to A.D. 1760.

Mkandawire, T. (2001). Thinking about developmental states in Africa. Cambridge Journal of Economics, 25(3), 289-313. Doi: 10.1093/cje/25.3.289

Singh, N, J. (in press), The theory and practice of building developmental states in the global South: an introduction. Third World Quarterly.

Tilly, C. (1985). War making and state making as organized crime. In P. Evans, D. Rueschemeyer, \& T. Skocpol (Eds.), bringing the state back in (pp. 169-191). doi:10.1017/CBO9780511628283.008

Turton, D. (Ed). (2006). Ethnic federalism: the Ethiopian experience in comparative perspectives. Oxford: James Currey Ltd

Varshney, A. (2002). Ethnic Conflict and Civic Life: Hindus and Muslims in India. New Haven: Yale University Press.

Wade, R. (1990). Governing the market: economic theory and the role of government in East Asian industrialization. Princeton: Princeton University Press.

World Bank. (2016). Ethiopia $\quad$ overview. Retrieved from http://www.worldbank.org/en/country/ethiopia/overview

Young, C. (2012). The postcolonial state in Africa: fifty years of independence, 1960-2010. Madison: University of Wisconsin Press. 